\title{
The British Empire Exhibition.
}

\section{Exhibition of Pure Science arranged by the Royal Society-I.}

$\mathrm{A}^{\mathrm{s}}$ $S$ part of the scheme for the participation of H.M. Government in the British Empire Exhibition at Wembley, an Exhibition of Pure Science has been organised. The arrangements are in the hands of a strong committee appointed by the Royal Society under the chairmanship of Sir Richard Glazebrook, Mr. T. Martin being the secretary, and the funds have been provided through the Department of Overseas Trade. A valuable little handbook dealing with the physical and biological exhibits has been issued at the price of one shilling, and a notice of this appeared in NATURE of May 24, p. 756 . The exhibits which it describes will be found in the Government Pavilion not far from the railway station inside the Exhibition grounds, but the committee is also responsible for certain exhibits in the scientific section of the Chemical Hall in the Palace of Industry, which has already been described in NATURE. Owing to the limited space available the exhibits and demonstrations cannot all be shown at once, but this difficulty has been met by arranging a rotation, and visitors can find out from the handbook during what periods it will be possible to see items in which they are specially interested.

The space available bears in fact a very small proportion to the total area occupied by "Wembley," but the thoughtful visitor will recognise that the two rooms devoted to pure science represent the seed from which has sprung the material civilisation so lavishly represented elsewhere; or rather, let us say, the hormone which has stimulated that growth of prosperity which is such an important element in Empire. He will be insensible indeed if he can leave them without feeling profound pride in the contributions which British men of science have made and are making to modern knowledge, for it is these that are illustrated by the exhibits in question.

Between science and the Empire there is a connexion which is not far to seek. The precautions against plague and famine, which constitute an important function of the British Raj in India, the treatment of tropical diseases, which is bringing advantage to others of our fellow-subjects, and the industries the products of which are displayed in various parts of the Exhibition grounds-these and other benefits of British civilisation would be condemned to a stunted empiricism but for the debt they owe to the laboratory investigator. We may even go further and trace a by no means imaginary connexion between the spirit of science and the political ideals of the Empire-the uncorrupt administration of justice, the maintenance of public order, the education of the component peoples in the art of democratic government-for these things are closely akin to that frank search for truth and ascendancy of reason over passion which are necessary to success in science, and must progress with every advance in influence which accrues to scientific men. In its mission of bringing peace to the world and keeping the peace within its own borders, the Empire receives from science the most powerful instrument it possesses in the development of transport and signal communication which is constantly bringing all races into closer touch with one another: and the same cause is served by commerce, which depends through industry and applied science on the researches of men of science. Such facts are familiar to every reader of NATURE, but it is well that the Royal Society's exhibition should bring them hoine to the general public, for the latter is still capable of the ridiculous inference that because men of science performed a patriotic duty during the War, they must be assumed to spend their whole time in the occupations which then brought them unwontedly into the field of view.

By directing attention to the methods of science, the exhibition helps the public to grasp the difference between discovery and invention, a distinction which is always confounded in the popular mind with undesirable consequences: and by illustrating the laborious steps, necessitating the co-operation of many minds, by which knowledge has to be won, it fortifies the visitor against the extravagant claims of the pseudoscientific person, whose success in enlisting popular attention must adversely affect the prestige of science in the long run. It is far easier to explain the results and conclusions of science to the uninitiated than to convey a serious conception of its methods : yet it is the methods that are of real importance, for the results are often provisional and embryonic, and it is in the introduction of scientific method into common affairs that the body politic can most profitably learn from science at the present time. By confining his attention to some limited part of the available subjectmatter, examining the relevant apparatus, studying the descriptions in the handbook, and making full use of the demonstrators' services, a non-scientific inquirer will be able to get a very good idea of the way a scientific worker goes about his work.

In the physiological section it is interesting to notice the extensive use which is being made of the refined methods of the physicist for the study of living reactions. The electric changes associated with muscular action are demonstrated with a string galvanometer, by which the action of the heart can be indicated in a most interesting way. A hot-wire microphone of the kind originally invented for sound-ranging in war is also applied to the study of heart phenomena, the air displacement caused by the pulse in a rubber tube applied to the neck being measured with great sensibility. Such methods, with which the name of Prof. A. V. Hill is associated, are also of value in diagnosis. Thermopiles are used for measuring the heat liberated during muscular work, and Prof. E. P. Cathcart exhibits a walking platform (until July $3 \mathrm{I}$ ) and a bicycle ergometer (from August I) by means of which the physiological effects of a man's exertions can be studied under constant but controllable conditions. For example, the exhaled gases can be collected in a Douglas bag and analysed in a Haldane apparatus, whence the total production of carbon dioxide corresponding to a given amount of work can be found, and it is stated that the energy input and output for the human body can be accounted for and balanced

$$
\text { No. } 285 \text { O, voL. I I } 3]
$$


to within one per cent. The katharometer also is used for the estimation of carbon dioxide. Two examples (due to Dr. H. Hartridge and Mr. F. J. W. Roughton) are shown of chemical apparatus devised for physiological purposes, but applicable over a wider field, namely, a reaction-velocity apparatus and the " reversion spectroscope," both of which were intended in the first instance for research on the oxygenation of the blood.

Plant physiology is represented by some experiments of Prof. Blackman on plant growth and respiration and the effect of gravity and light on plants. Physiologists seem to have a lingering predilection for smoked paper for chronographic purposes : one would think that the cleanlier methods common in physics would be less troublesome and a great deal less messy. Of greater scientific than æsthetic value is Prof. Starling's heart-lung apparatus, in which the blood stream from the heart and lungs of a living animal is diverted from the trunk into an artificial circulatory system where conditions as to pressure, etc., can be controlled for studying the behaviour of the organs in question. This apparatus affords a good opportunity for explaining to the public (in view of what is done in the name of science abroad) what the practice of British investigators is as regards the use of anæsthetics in such cases. An interesting modern topic is illustrated by a demonstration due to Dr. D. T. Harris of the effect of ultra-violet light on isolated tissue. The tissue is kept alive by immersion in Ringer's fluid and its tone is indicated by the movements of a lever attached to it. The normal rhythmic movements are disturbed as soon as ultra-violet light falls on the tissue. Dr. L. T. Hogben's study of colour change in frogs and salamanders in response to changes of temperature and other external factors, apparently due to a secretion of the pituitary body, is of great interest.

A number of exhibits, largely on loan from the Natural History Museum, indicate the nature and extent of biological research in its wider aspect, and bring out some striking facts bearing on the evolution of species. Methods of preserving plants are illustrated by some beautiful specimens (Mr. R. D'O. Good), and the vast amount of work that has been done by organised expeditions and by individuals in biological exploration is shown by a tabular statement of the increase in some of the collections at the Museum. As an example of this kind of achievement the Terra Nova expedition is specially represented by means of charts, reports, and specimens.

The vast field of evolutionary theory is represented by series of specimens chosen to exemplify certain of its more important aspects. There are fossil series showing the evolution of elephants and oysters, and evolution with divergence of character in the case of chalk polyzoa. Recapitulation is illustrated by Prof. J. P. Hill's admirable examples of egg-laying mammals in various stages of development, and by a collection of carboniferous corals which show the relation between ontogeny and phylogeny in a particularly obvious way. Man is represented by models of the Piltdown and other skulls, the actual and the reconstructed parts being shown in different colours. Collections of butterflies and beetles, for which Prof. E. B. Poulton and Dr. C. J. Gahan respectively are responsible, are strikingly arranged to illustrate mimicry, models being shown side by side with their various mimics, while the variation with locality of such a species as Papilio dardanus is fully brought out in relation to the distribution of the relevant models.

The key to the mystery of evolution lies with genetics, and it is perhaps a matter for criticism that in this admirable exhibition the subject of Mendelian inheritance, which owes so much to British workers, is represented by only a single example, that of the synthesis of a white breed from coloured breeds of fowls (Prof. R. C. Punnett). Biologists appear to differ strongly as to the extent and significance of this type of inheritance, but as the standard examples are definite and readily understandable, and illustrate well the application of rigorous numerical principles, they would seem to be particularly appropriate to an exhibition of the present kind-especially in view of the great social as well as theoretical importance of heredity. Attention is directed to one of the most remarkable of current problems in Dr. F. A. E. Crew's exhibits in connexion with sex-reversal in fowls, the unmaidenly conduct of forty old hens providing much food for reflection. The occasional assumption of the male plumage has long been known, but it is here shown that this is accompanied by profound internal changes, the study of which must illuminate the whole subject of sex differentiation.

Mr. C. Tate Regan, by means of specimens showing the remarkable effect of environment on isolated specific characters in fish, challenges thought on a fundamental evolutionary problem for which one hundred and twenty-three years of controversy does not appear to have provided a generally accepted solution.

The influence of climate and soil on vegetation is illustrated by a comparison of the Cretaceous and contemporary flora of Greenland (Prof. A. C. Seward). The fossil plants exhibited were collected from the muds and sands of estuaries and freshwater lakes of Disko Island, Uppernivik Island, and the west coast of the mainland (lat. $70^{\circ} \mathrm{N}$.), and include species of Gleichenites scarcely distinguishable from Gleichenias now widely distributed in the tropics and other plant remains closely related to present-day plants of temperate and tropical regions. It seems that while conditions in Greenland to-day are very similar to those prevalent in the British Isles during the last great Glacial period, in former ages the climate must have been at least as genial as that of Central Europe at the present time. The accurate determination of the distribution of plant-groups is a very laborious proceeding if a survey has to be conducted on the ground over a large area, and, indeed, is frequently impracticable. In many such cases the aeroplane can now be pressed into service and the survey accomplished by aerial photography. The photographs exhibited by $\mathrm{Mr}$. H. Hamshaw Thomas bring out the effects produced by stretches of different types of vegetation. They have been taken in various parts of the world, those from Blakeney Point, where new land is being recovered from the sea, being perhaps the most interesting.

In a later article an account will be given of the sections devoted to physics and geophysics.

C. W. H.

NO. 285 O, VOL. I I 3$]$ 